\title{
Zbornik mednarodne konference Jezikovna raznolikost in nacionalni jeziki v visokem šolstvu
}

\author{
Barbara Jelen
}

Cobiss: 1.19

Nacionalni jeziki v visokem šolstvu, ur. Marjeta Humar - Mojca Žagar Karer, Ljubljana: Založba ZRC, ZRC SAZU, 2010, 129 str.

Na pobudo ${ }^{1}$ Evropske zveze za terminologijo (EAFT), katere član je tudi Inštitut za slovenski jezik Frana Ramovša ZRC SAZU, je od 19. do 20. novembra 2009 v Ljubljani potekala mednarodna konferenca $\mathrm{z}$ naslovom Jezikovna različnost in nacionalni jeziki v visokem šolstvu. Omenjenima organizatorjema se je priključilo še Evropsko združenje državnih jezikovnih ustanov (EFNIL), finančno pa so konferenco podprli Sektor za slovenski jezik Ministrstva za kulturo Vlade Republike Slovenije, Javna agencija za raziskovalno dejavnost Republike Slovenije in Délégation générale à la langue française et aux langues de France iz Pariza. Na konferenci so sodelovali predstavniki iz več evropskih držav: Belgije, Romunije, Španije, Francije, Nemčije, Latvije, Nizozemske, Madžarske, Irske, Danske, Švedske, Portugalske, Hrvaške, Cipra in seveda iz Slovenije. Udeleženci so se posvetili predvsem problematiki nacionalnih jezikov ter njihove vloge $\mathrm{v}$ znanosti in pri poučevanju $\mathrm{v}$ času zmeraj večjega vpliva globalnega jezika. ${ }^{2}$

Angleščina namreč postaja glavni medij poučevanja v visokem šolstvu in glavni medij v akademskih publikacijah v mnogih državah, kot je v svojem prispevku izpostavila Fidelma Ní Ghallchobhair (Irska). Obstajajo lahko različni vzroki za tako bliskovito širjenje kakega jezika, a za angleščino sta zagotovo najpomembnejša dva: vzpon angleškega imperija in rast svetovne trgovine. To je avtorica ponazorila z naslednjimi podatki: v 14. stoletju je angleščina na Otoku zamenjala latinščino kot učni jezik v šolah in francoščino kot jezik sodišč; v naslednjem stoletju je prihod tiskarne vplival na standardizacijo pisane angleščine, razširitev besedišča in skladnje; Shakespeare je do smrti leta 1616 v angleški leksikon prispeval kar približno 2000 besed; leta 1702 je bil izdan prvi dnevni časopis v angleščini The Daily Courant; angleška kolonizacija v Severni Ameriki je sprožila ustvarjanje narečja; v

1 Predstavitev zbornika je nastala v okviru študija slovenskega jezika in književnosti na Filozofski fakulteti Univerze v Mariboru pri predmetu Slovenski jezik in globalizacija pod mentorstvom nosilke, red. prof. dr. Irene Stramljič Breznik.

2 Zbornik s te konference je dosegljiv na spletnem naslovu http://bos.zrc-sazu.si/knjige/ Nacionalni\%20jeziki\%20v\%20visokem\%20\%C5\%A1olstvu.pdf. 
18. stoletju je Samuel Johnson izdal popularni slovar, James Cook je odkril Avstralijo, kjer je bila ustanovljena britanska kolonija; sledila je industrijska revolucija in posledično tudi nove poimenovalne potrebe; konec 20. stoletja pa so ZDA postale svetovna velesila. Ne moremo trditi, da se je angleščina razširila zgolj zaradi tega ali onega razloga, lahko pa bi rekli, da je bila na pravem mestu ob pravem času in je tako k njeni globalizaciji pripomoglo prav vsako dejanje $\mathrm{v}$ zgodovini angleške civilizacije, zato je postala novi akademski, multimedijski in globalni jezik. Pozablja pa se na dejstvo, da je angleščina širila svoje besedišče tudi s pomočjo drugih jezikov, npr. latinščine in francoščine, ki sta po oceni nekaterih strokovnjakov prispevali kar po 29 odstotkov besed (str. 123-124).

Večkulturnost je razumljena kot prepletanje in součinkovanje kultur starih in novonastalih držav, vendar se zaradi globalnega pretoka kapitala in močnega vpliva angleščine pojavlja težnja po nadnacionalnosti, v kateri je nevarnost, da se opušča lastna nacionalna identiteta in jezik. Gerhard Stickel (Nemčija) ugotavlja, da znotraj področij znanosti profesionalci uporabljajo angleščino tako za razne publikacije kot za poučevanje in posredovanje navodil študentom na univerzah. Tisti, ki poučujejo na univerzi, berejo znanstvene revije ali obiskujejo konference, se pogosto srečujejo $\mathrm{z}$ oviro, ko morajo svoja predavanja in prispevke pripraviti $\mathrm{v}$ tujem jeziku, saj za to potrebujejo več časa in denarja, če jezika ne obvladajo (str. 19). Matej Accetto (Slovenija) izpostavlja, da znanstveni jezik lahko postane talec globalnih interesov, ko se pojavi potreba po zagotavljanju konkurenčnosti ali preverljivosti znanstvenega dela, saj je objavljanje $\mathrm{v}$ maternem jeziku pogosto ovrednoteno slabše kot objavljanje $\mathrm{v}$ tujih jezikih (str. 29). Ta problem je prisoten tudi v Sloveniji; tako v svojem prispevku Alojzija Zupan Sosič (Slovenija) navaja Merila za volitve v nazive visokošolskih učiteljev, znanstvenih delavcev in sodelavcev, iz katerih je razvidno, da je slovenski znanstveni jezik vrednoten slabše, npr. del monografije v tujem jeziku se točkuje z 8 točkami, v maternem jeziku le s 4 točkami, s polovičnimi točkami pa se ocenjuje tudi pri strokovni in uredniški dejavnosti (str. 65). Georges-Louis Baron in Eric Bruillard (Francija) menita, da se Evropska komisija sicer nagiba $\mathrm{k}$ večjezičnosti, vendar so evropski znanstveni/strokovni izsledki zdaj pisani skoraj izključno v angleščini. Izražanje človekovih idej v tujem jeziku pa vodi $\mathrm{k}$ poenostavitvi človekovih misli, zmanjša posebnosti, povezane s kulturo te osebe, in zanemarja reference, ki niso prevedene $\mathrm{v}$ angleščino (str. 80-81).

Bolj ko angleščina postaja dominantna na znanstvenih področjih, bolj nacionalni jezik izgublja svojo vrednost. Stickel pravi, da to lahko privede do tega, da se materni jezik ne bo več uporabljal na pomembnih področjih v politiki, gospodarstvu in znanosti, ampak se bo njegova raba omejila le na področja, kot so družina, prijatelji in razne skupnosti (str. 19-20). Takšna zamenjava jezika pa bi povzročila še dodatne konflikte. Jan Roukens (Nizozemska) opozarja, da bi vsakršna nadvlada nematernega jezika privedla tudi do družbenih in kulturnih napetosti, političnih nemirov in stagnacije. Podoben položaj nam je znan tudi izpred 500 let, ko je latinščina na škodo nacionalnih jezikov prevladovala na znanstvenem, kulturnem in verskem področju (str. 100-101). Tomaž Erjavec (Slovenija) se v svojem prispevku strinja, da nova terminologija prihaja skoraj izključno iz angleškega jezika, vendar 
to ni vzrok, da se nacionalni znanstveni jezik ne bi mogel ohraniti. Rešitev, ki jo predlaga, je, da bi se za vsak pojem uvedle slovenske ustreznice, pri katerih bi se ohranile izvorne latinske osnove, če pa termini nimajo latinske osnove, se svetuje prevod s slovensko ustreznico, ki bi ohranila čim več elementov izvirnika (str. 110). Tako se pri nas ohranja terminologija v elektrotehniki in farmaciji, kjer se strokovne besede ohranjajo v strokovnih revijah in slovarjih. Slovenske elektrotehniške strokovne besede pomagajo gojiti tudi slovenski elektrotehniški učbeniki, kot navaja Tadej Bajd (Slovenija). Georgeta Ciobanu (Romunija) se prav tako strinja, da je splošni trend adaptiranja izposojenih pojmov v jezik prejemnik naravni protiukrep področni izgubi nacionalnega jezika. V svojem prispevku omenja, da ima v Romuniji večina terminoloških slovarjev s področij, ki so zelo izpostavljena vplivom angleščine, za vsak vpis tudi ustreznico v romunščini. Nekatere ustreznice v romunščini sicer niso prednostna izbira pri objavi, a so se vseeno ohranile v slovarju za možno poznejšo uporabo (str. 115). V mnogih znanstvenih zbornikih ali revijah lahko opazimo, da se pojavljajo povzetki prispevkov ne le v tujem, temveč tudi v nacionalnem jeziku. Hrvati se zavedajo, da to ni dovolj za ohranitev terminologije, zato poskušajo, kot v svojem prispevku navajata avtorici Maja Bratanić in Ana Ostroški Anić (Hrvaška), ohranjati terminologijo svojega jezika tako, da izdajajo knjige večinoma v hrvaškem jeziku (str. 44). Georges-Louis Baron in Eric Bruillard (Francija) izpostavljata tudi primer Francije, ki svoj jezik ohranja s konferencami in z objavljanjem strokovnih revij v francoščini (str. 82-83).

Zapostavljanje objav v slovenščini pa ni škodljivo le z vidika razvijanja terminologije, temveč tudi z vidika nacionalnega jezika kot jezika visokošolskega univerzitetnega izobraževanja, izpostavlja Monika Kalin Golob (Slovenija) (str. 68). Večina ljudi, ki študira v Sloveniji, bo po diplomi svoje znanje uporabljala $\mathrm{v}$ slovenskem jezikovnem prostoru, torej je obvladanje stroke v slovenskem jeziku temeljni pogoj njihovega poklicnega delovanja. Pojavlja pa se vprašanje, ali jim bodo to znanje lahko dajali profesorji, ki pišejo o stroki le še v tujem jeziku. Študenti se občasno soočajo tudi s težavo, ko morajo literaturo predelati v tujem jeziku, pa niti nimajo dovolj znanja tega jezika, zatorej je še dodatna potreba po literaturi v slovenskem jeziku. V Sloveniji je tako uradni jezik kot jezik poučevanja slovenščina, zato imajo študenti pravico do vzgoje in izobraževanja v svojem jeziku, kar se nanaša tudi na gradivo (str. 68). Na Hrvaškem se sicer od študentov pričakuje, da znajo gradivo uporabljati v tujem jeziku, vendar je večina knjig izdanih v hrvaškem jeziku, kar v svojem prispevku posebej omenjata Maja Bratanić in Maja Ostroški Anić (str. 44). Ágota Fóris (Madžarska) piše, da Madžari ohranjajo madžarščino kot jezik poučevanja tako, da so angleški, nemški in francoski jezik dovoljeni posebej za tuje študente in le v primeru, če se izobraževanje izvaja že v madžarščini. Ostali jeziki so prisotni na področju humanistike, kjer se izvaja študij kakega tujega jezika, nekateri jeziki pa se dovoljujejo tudi pri določenih programih, kjer živijo manjšine tega jezika (str. 72-73). Podobno tudi Maja Bratanić in Maja Ostroški Anić navajata, da so na Hrvaškem programi v angleščini neobvezni/izbirni in se izvajajo le za tuje študente ali študente humanistike, ki se učijo tega jezika (str. 45). Na Cipru, katerega jezikovno stanje v prispevku obravnava Marilena Karyo- 
lemou (Ciper), ima grščina še vedno močno vlogo v visokem šolstvu, čeprav so še vedno razdvojeni med ustanovami, ki uporabljajo angleščino, in tistimi, ki imajo za jezik poučevanja grščino. Razlog, da ima grščina tako močno vlogo v javnem visokem šolstvu na Cipru, je dejstvo, da jezik močno vpliva na etnična gibanja in identifikacijo otoka. To je tudi razlog, da se izogibajo nadvladi rabe tujih jezikov, še posebej angleščine (str. 41). Pomembnosti uporabe lastnega jezika se zavedajo tudi na Švedskem. Anna-Lena Bucher (Švedska) omenja, da tam zakon javnim ustanovam nalaga odgovornost za zagotavljanje dostopnosti, uporabe in razvoja terminologije v švedščini, in sicer znotraj določenega področja. Švedski jezikovni svet preverja, kako visokošolske ustanove na Švedskem izpolnjujejo svojo dolžnost pri zagotavljanju, da se švedščina uporablja v izobraževanju (str. 117-118). Soočanje z globalizacijo angleščine in ohranjanjem jezika pa je povzročilo večje težave na Irskem. Seosamh Mac Donnacha (Irska) navaja primer Nacionalne univerze v Galwayu, ki si je ves čas prizadevala ohraniti irščino, vendar ni mogla ostati v koraku $\mathrm{z}$ angleškimi programi. Leta 2000 je bila objavljena Strategija za razvoj tretje ravni $\mathrm{v}$ šolstvu $\mathrm{z}$ usmerjenostjo $\mathrm{k}$ večji rabi irščine na desetih akademskih področjih, kot so npr. prevajalstvo, jezikovno načrtovanje, informatika, komunikacijske vede itd. Ta področja so bila predlagana kot prioritetna in $\mathrm{s}$ tem se je irščina $\mathrm{v}$ visokem šolstvu ohranila (str. 52-55). Nekoliko drugače pa problem dvojezičnosti v območju Evropske unije, še posebej v Latviji, izpostavljata Ina Druviete in Jānis Valdmanis (Latvija). Ugotavljata, da je veliko univerz $\mathrm{v}$ državah, kjer angleščina ni uradni jezik, dodalo angleščino kot jezik poučevanja. Študenti na Danskem, Švedskem, Nizozemskem in celo v Nemčiji čedalje bolj postajajo tekoči govorci angleščine, ne uspevajo pa kot profesionalci v uradnem jeziku države. Področna izguba jezika ima tako neposreden vpliv na druga področja in na kakovost jezika na splošno. Latvija se sooča s konfliktom v dvojezičnosti: po eni strani evropska integracija daje nove možnosti za nadaljnji razvoj latvijskega jezika, po drugi pa so prisotni dejavniki, ki favorizirajo globalno razširjene jezike, kot so angleščina, francoščina in nemščina. Za ohranitev nacionalnega jezika so v Latviji leta 2006 uvedli zakon, ki preprečuje izgubo uradnega jezika $v$ visokem šolstvu in znanosti; $v$ državno financiranih ustanovah je latvijščina uradni jezik poučevanja, raba tujih jezikov na študijskih programih pa je omejena (str. 92-93).

Kot je razvidno iz prispevkov $\mathrm{v}$ zborniku, se $\mathrm{z}$ največjimi težavami sooča Danska, saj angleščina danščino vse bolj izpodriva. Po podatkih, ki jih v članku posreduje Niels Davidsen-Nielsen, je na prvi stopnji 7 programov v angleščini in 10 $\mathrm{v}$ danščini, na drugi stopnji pa je kar 19 programov v angleščini in le $11 \mathrm{v}$ danščini. V primeru nadvlade angleščine kot jezika poučevanja bi tako prišlo do resnih težav zaradi področne izgube danščine; akademska raven bi padla, ker niti študenti niti profesorji nimajo tako dobrega znanja angleščine. Po dostopnih podatkih se je Danska sicer odločila, da se mora danščina ohraniti kot jezik poučevanja in raziskovanja na univerzah, vendar naj to ne bi bilo pravno zavezujoče. Zato je vprašljivo, ali je to dovolj za ohranitev (strokovnega) jezika (str. 87-89).

Ena od vrednot skupnosti je skrb za lasten jezik. Država ga lahko zaščiti na različne načine. V Sloveniji za status in razvoj slovenščine in za razvoj zlasti doma- 
če terminologije skrbi poleg univerz tudi Inštitut za slovenski jezik Frana Ramovša ZRC SAZU, v njegove slovarske projekte pa so vse pogosteje vključene tudi različne gospodarske družbe in državne ustanove s svojimi strokovnjaki, kot v svojem prispevku omenja Andreja Žele (Slovenija) (str. 128-129).

Različni avtorji se strinjajo, da materni jezik pomembno prispeva $\mathrm{k}$ nacionalni identiteti, h kakovostnemu izražanju človekovih misli in k nadaljnjemu razvoju na vseh področjih znanosti in družbe, zato se tudi pojavlja potreba po spoštovanju jezikovne raznolikosti. Različne discipline znanosti tako ne bodo le ohranile večjezičnosti na svojih področjih, ampak bodo s tem tudi prispevale k ohranitvi in nadaljnjemu razvoju evropske multikulturnosti kot posebne vrednote sodobne civilizacije, v kateri je mogoče odkrivati enakost v različnem in različnosti v enakem. 